\title{
Sulfate reduction in bentonite
}

BIRGITTA E KALINOWSKI", PATRIK SELLIN, DANIEL SVENSSON

Svensk Kärnbränslehantering $\mathrm{AB}$, Solna Sweden

*Birgitta.Kalinowski@skb.se

In the Swedish KBS-3 concept highly radioactive used nuclear fuel is emplaced in copper canisters embedded in compacted bentonite deep down ($500 \mathrm{~m}$ ) in crystalline rock (designed lifetime is $100-1000 \mathrm{ka})$. The bentonite is protecting the canister chemically and physically from the surroundings. One of the main functions of the bentonite is to inhibit activity of microbes, e.g. sulfate reducing bacteria (SRB). Under saturated conditions the microbial sulfate reduction will be limited if the bentonite density is sufficient. Current observations indicate that microbes become inactive at the high swelling pressure $(>2$ $\mathrm{MPa})$. Experimental results indicate that there is a clear cut-off in dry density where sulfide production ceases. This cut-off is different for different bentonites meaning that there are other factors than the degree of compaction that affects the microbial activity.

Before the bentonite is water saturated, there may be a window of opportunity when there is high enough relative humidity (RH) for SRB to be active. This study aimed at finding out if there is a moisture threshold limit for microbial sulfide production in the bentonite.

Tube experiments were performed in $\mathrm{N}_{2^{-}}$ atmosphere where an open glass tube with bentonite, gypsum, lactate, SRB, and nutrients were emplaced in a plastic tube containing either pure water or saturated salt solution setting the RH. Microbiological sulfate reduction was detected to occur when the microbes had access to liquid water, while no sulfide production was detected when the microbes were restricted to a RH of $75-100 \%$. 